\title{
Promote buckling up and save a child's life
}

\author{
Y Ferreira, ${ }^{1}$ MB ChB, DipPEC, DipForMed (Clin); A B van As, ${ }^{2} \mathrm{MB}$ ChB, MMed, MBA, FCS (SA), PhD \\ ${ }^{1}$ Trauma Unit, Red Cross War Memorial Children's Hospital, and Division of Paediatric Surgery, Faculty of Health Sciences, \\ University of Cape Town, South Africa \\ ${ }^{2}$ Childsafe South Africa, Cape Town; Trauma Unit, Red Cross War Memorial Children's Hospital, and Division of Paediatric Surgery, \\ Faculty of Health Sciences, University of Cape Town, South Africa
}

Corresponding author: A B van As (sebastian.vanas@uct.ac.za)

Road traffic crash (RTC) injuries are the leading cause of child mortality and morbidity in South Africa for children between the ages of 1 and 18 years. The World Health Organization's Global Status Report on Road Safety 2015 rated the African continent's roads the world's most dangerous. After pedestrian injuries, passenger injuries are the most lethal. There is no doubt that a seat belt is the single most effective feature in a vehicle to reduce the severity of injury to the vehicle's occupants; wearing a seat belt reduces the risk of fatal injury by up to $50 \%$ and $75 \%$ for front seat and rear seat occupants, respectively. Children have specific anatomical and physiological limitations that render them more vulnerable to serious injury, but the prevention of childhood RTC injuries has unfortunately not received the deserved attention by the medical fraternity. There is currently ample evidence that the use of seat belts and appropriate child restraint seats has led to a significant reduction in RTC fatalities and injuries. It is, therefore, the duty of every healthcare worker to lead by example by using child restraints correctly, and actively encouraging the use of these devices for all their clients and patients.

S Afr Med J 2017;107(4):292-294. DOI:10.7196/SAMJ.2017.v107i4.12433

Behind each health statistic is a human being, a family, and a community. This is especially true with regard to the devastating road traffic crash (RTC) toll on South African (SA) roads.

RTC injuries are the leading cause of childhood trauma-related mortality and morbidity in SA. Up to $40 \%$ of children who present to Red Cross War Memorial Children's Hospital (RCWMCH), Cape Town, SA with RTC injuries required admission owing to the severity of their injuries. Low- and middle-income countries exhibit a disproportionately higher burden of RTC injuries and deaths, but have a relative lack of analytical data. ${ }^{[1]}$

In 2010, 1.3 million deaths worldwide were caused by RTCs. ${ }^{[2]}$ Twentyone percent of these deaths occurred among children. ${ }^{[3]}$ Increasing motorisation has led to a higher number of crashes and injuries to vehicle occupants, particularly in low- and middle-income countries. In the last two decades there was a $46 \%$ increase in deaths due to RTCs. ${ }^{[2]}$

The World Health Organization (WHO)'s Global Status Report on Road Safety 2015 rated Africa's roads the world's deadliest. SA's road fatalities were 25.1/100 000 population, a little below the African average of $26.6 / 100000$. This is, however, well above the $9.2 / 100000$ population for Europe and the worldwide estimate of $17.4 / 100000{ }^{[4]}$

\section{Road traffic crash statistics in Cape Town}

RTC injuries are the leading cause of death in 5 - 14-year-old children in Cape Town. ${ }^{[5]}$

RCWMCH is a public institution that serves as a referral paediatric hospital for children $<13$ years of age in the greater Cape Metropole.

Pedestrian RTCs are the most commonly observed mechanism in RTC injuries in all age groups seen at RCWMCH (71\%), with a male predominance of $64 \%{ }^{[1]}$

The second most commonly observed mechanism of road trafficrelated injury is unrestrained vehicle passengers $(11 \%)$. Children $<1$ year of age are particularly at risk (35\%). ${ }^{[1]}$ Of the 4517 documented passengers in RTCs seen over a 25 -year period, only $27 \%(n=1222)$ were restrained
(Fig. 1). Despite a quarter of a decade's campaigning to promote road safety, this number has not improved significantly from 1991 to 2015 (Fig. 2) ${ }^{[6]}$

\section{Seat belts and child restraints}

A seat belt is the single most effective feature in a vehicle that can reduce the severity of the occupants' injuries resulting from RTCs. Per

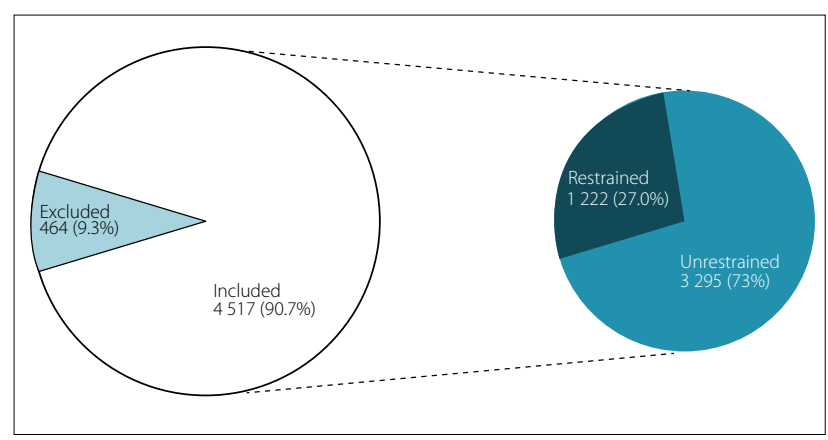

Fig. 1. Distribution of passengers in RTC cases $(\mathrm{n}=4981)$ at $R C W M C H$ over a 25-year period (1991-2016).

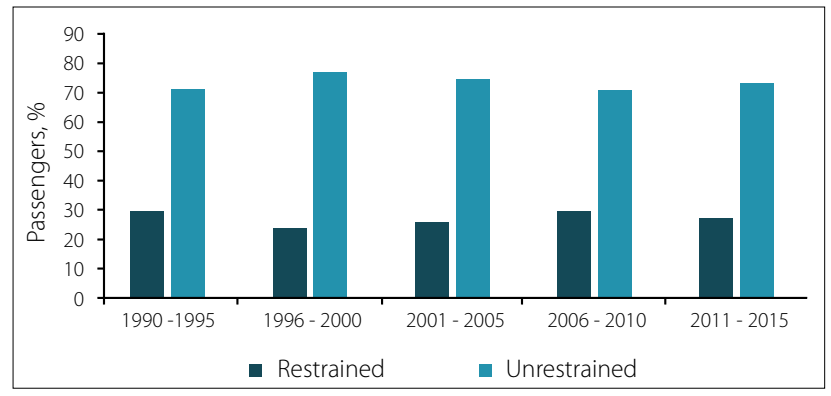

Fig. 2. Comparison between restrained and unrestrained passengers according to year of injury. 
the WHO's Global Status Report on Road Safety 2015, wearing a seat belt reduces the risk of fatal injury by up to $50 \%$ and $75 \%$ for front seat and rear seat occupants, respectively. ${ }^{[4]}$

The seat belt was invented by an English engineer, George Cayley, in the late 1800s. The purpose of these belts was to help keep pilots inside their gliders. ${ }^{[7]}$ The three-point lap/shoulder belt, as we know the seatbelt today, was invented by the Swedish engineer and inventor, Nils Bohlin, in 1958. The 1959 Volvo was the first car to be fitted with the three-point lap/shoulder belt as standard equipment. Before 1959, only two-point lap belts were available in motor vehicles. ${ }^{[8]}$

Since 1959, engineers have worked to enhance the three-point belt, but the basic design remains Bohlin's. Volvo made the new seat belt design available to other motor vehicle manufacturers free, in the interest of public safety. When Bohlin passed away in 2002, Volvo had estimated that the seat belt had saved more than one million lives in the four decades since its introduction. ${ }^{[8]}$

Since the Vienna Convention on Road Traffic of 1968, the wearing of safety belts has been compulsory for drivers and passengers of motor vehicles, unless domestic legislation granted exception. Legislation for the compulsory wearing of seat belts was first introduced globally by the Government of the State of Victoria, Australia, in $1970 .{ }^{[9]}$ SA only introduced seat belt legislation in 1973 and updated it in the National Road Traffic Act No. 93 of 1996. ${ }^{[10]}$

The three-point lap/shoulder seat belt aims to:

- prevent the occupant from being ejected from the vehicle upon impact

- prevent ejection, i.e. ejection from a vehicle results in a 5 - 8 times higher chance of death compared with a non-ejected occupant

- reduce the risk of contact with the interior of the vehicle, i.e. prevent the occupant from being flung forward and hitting the steering wheel, dashboard, or the seat in front of them

- prevent injury to other occupants. Unrestrained rear-seated passengers can be flung forward and hit other occupants

- distribute the forces of a crash over the strongest parts of the human body, thereby reducing the risk of internal injury. ${ }^{[11]}$

The three-point lap and diagonal seat belt was designed for adults. In the case of children of varying size and weight, and the different relative proportions of their bodies, adult seat belts are not optimally effective at preventing ejection and injury. ${ }^{[11]}$

Children have specific anatomical and physiological limitations that render them vulnerable to serious injury. A smaller portion of a child's abdomen is covered by the pelvis and rib cage, leaving it unprotected and at higher risk of injury. A child's rib cage is also more likely to bend rather than break, resulting in energy from the collision being transferred to the internal viscera. ${ }^{[1]}$

At birth, an infant's head is approximately a quarter of their total length and about one-third of their body weight. Furthermore, children's skulls are pliable up to the age of 24 months. Even low-energy forces can result in cranial deformity and brain injury. The smaller the child, the lower the force needed. ${ }^{[11]}$

Adult passengers often hold infants and young children in their arms, believing that they will keep them safe in the event of a collision. This is physically impossible and a dangerous myth. During impact, the weight and velocity of an adult body can magnify into a potentially lethal force, crushing the child to death. Infants and children therefore need a child restraint system that accommodates their size and weight, and can adapt to the different phases in their development. ${ }^{[6]}$

Correctly applied, child restraints reduce the likelihood of a fatal crash by $\sim 70 \%$ among infants ( $<1$ year of age) and between $54 \%$ and $80 \%$ among young children ( $1-4$ years old).$^{[4,12,13]}$ Unrestrained children in RTCs are found to have a higher injury severity and are more likely to need urgent medical intervention compared with children who were properly restrained. ${ }^{[13]}$

Failing to apply adequate child restraints is a major risk factor for injury to young children in RTCs. Despite extraordinary success in reducing deaths and serious injuries, the rate of use of appropriate child restraints in motor vehicles in SA remains dismal. Rates as low as $10 \%$ have been observed by Kling et al. ${ }^{[14]}$ in 2011.

\section{The National Road Traffic Act}

The SA law on seat belts is set out in Regulation 213 of the National Road Traffic Act (NRTA) No. 93 of 1996.

The law is very clear - all adult occupants ( $>14$ years of age or $>1.5 \mathrm{~m}$ in height) are obliged to wear seat belts if they are in a vehicle, including the driver of the vehicle and front and rear seat passengers. It is the driver's legal responsibility to ensure that the persons travelling in the vehicle wear a seat belt. ${ }^{[10]}$

Since 1 May 2015, children $<3$ years old are also permitted to travel in a car only if they are secured in a car seat. Motorists with unrestrained children $<3$ years old in their vehicle can be fined. This was a long-awaited and welcome addendum to the NRTA. This provision does, however, not apply in the case of a minibus, midibus or bus operated for reward, which creates problematic loopholes in the legislation to the detriment of the children it is supposed to protect. ${ }^{[15]}$

For children between the ages of $3-14$ years (or $<1.5 \mathrm{~m}$ in height) the law is unfortunately not clear. These children are obliged to

Table 1. Arrive Alive car seat information

\begin{tabular}{|c|c|c|c|}
\hline Rearward-facing infant car seat & Forward-facing child seat & Booster seat & Booster cushion \\
\hline Birth - 1 year & 9 months - 4 years & 4 - 6 years & $6-12$ years \\
\hline Up to $13 \mathrm{~kg}$ & $9-18 \mathrm{~kg}$ & $15-25 \mathrm{~kg}$ & $22-36 \mathrm{~kg}$ \\
\hline $\begin{array}{l}\text { Never put an infant car seat on } \\
\text { the front seat, especially if there is } \\
\text { a passenger airbag }\end{array}$ & \multirow{6}{*}{$\begin{array}{l}\text { Can be used until the child's } \\
\text { weight exceeds } 18 \mathrm{~kg} \\
\text { Can be used until the child grows } \\
\text { too tall for the height of the } \\
\text { adjustable harness }\end{array}$} & $\begin{array}{l}\text { Booster seats have a back and can } \\
\text { provide additional protection in } \\
\text { the case of a side impact }\end{array}$ & $\begin{array}{l}\text { Booster cushions do not have } \\
\text { an integral harness to hold the } \\
\text { child in place }\end{array}$ \\
\hline $\begin{array}{l}\text { Keep child in rearward-facing seat } \\
\text { for as long as possible }\end{array}$ & & \multirow{5}{*}{$\begin{array}{l}\text { Use until the three-point lap/ } \\
\text { shoulder seat belt fits the child } \\
\text { properly } \\
\text { Typically use when the child } \\
\text { reaches a height of } \sim 145 \mathrm{~cm}\end{array}$} & $\begin{array}{l}\text { The adult seat belt must be used } \\
\text { and adjusted correctly }\end{array}$ \\
\hline Move to forward-facing seat if the & & & Children who are tall enough to \\
\hline child has exceeded the maximum & & & wear an adult seat belt should be \\
\hline weight for the infant seat or if the & & & in the back seat until they are \\
\hline top of their head is higher than & & & 13 years old \\
\hline the top of the seat & & & \\
\hline
\end{tabular}


utilise seat belts only when these are present in a vehicle. The NRTA therefore does render it lawful for children to travel in a vehicle without any form of restraint. ${ }^{[10]}$ According to the WHO's Global Status Report on Road Safety 2015, 105 countries have seat belt laws in place that cover both front and rear seat passengers, while 53 countries have a child restraint law in place (based on age, weight or height) that restricts children from sitting in the front seat. ${ }^{[4]}$

The Arrive Alive campaign has published very useful car seat suggestions to clarify this dilemma (Table 1). ${ }^{[16]}$

Sadly, the impact of legislation on fatalities is often minimal. For instance, the Japanese road traffic law regarding compulsory child restraint seats for all children aged 0 - 5 years was implemented in April 2000. However, this legislation failed to result in a statistically significant reduction in child RTC occupant fatalities or injuries, as shown by Desapriya et al. ${ }^{[17]}$

Numerous efforts have to be made to increase compliance of the use of car restraint seats. Information and educational programmes for the public, safety seat loaner programmes and reward-based programmes are some of the options. ${ }^{[18]}$

SA is a developing country. Mobility in any shape and form is valuable, i.e. a bicycle is better than walking and a car represents prosperity. This is even more significant in rural areas, where people expose themselves to risks to travel to work, school or hospital.

One of such situations is passengers on goods vehicles (e.g. travelling on the back of a bakkie). In November 2016, the government published two amendments to the NRTA in the Government Gazette No. 40420, which will be effective from 12 May 2017: ${ }^{[19]}$

- Regulation 247 of the NRTA No. 93 of 1996 permits the conveying of passengers in the goods compartment of a vehicle if the sides of the vehicle are enclosed to a height of at least $350 \mathrm{~mm}$ above the seating surface or $900 \mathrm{~mm}$ above the surface on which the person is standing. ${ }^{[19]}$ Therefore, roughly the length of a ruler is offered as protection and there is no need for a roof covering.

- Regulation 250 of the NRTA No. 93 of 1996 states that 'No person shall on a public road carry any person for reward in the goods compartment of a motor vehicle. ${ }^{\text {[19] }}$

Neither of these regulations forbids the conveyance of persons in the goods compartment of a bakkie, regardless of whether they are children or not. Only if the conveyance is for reward, will it be prohibited.

\section{Medical practitioner's obligation}

Childhood trauma is a major cause of mortality and morbidity. The WHO expects that by 2020 it may be the primary disease globally. ${ }^{[20]}$

Most countries, including SA, define RTC injuries as the responsibility of the Department of Transport. Medical practitioners are responsible for dealing with the consequences of RTCs, but not for the prevention of injury. Worldwide there was remarkable success in changing lifestyle health concerns, such as smoking and obesity. ${ }^{[5]}$ Every healthcare worker, whether general practitioner, paediatri- cian or member of a nursing team, will fail our children by not emphasising the value of seat belts and the necessity of proper child restraints, and actively promoting the new legal requirements.

\section{Conclusion}

The prevention of RTC injuries has long been neglected by the medical profession.

There is ample evidence that the use of seat belts and appropriate child restraint seats has led to a significant reduction in RTC fatalities and injuries.

Every healthcare worker should lead by example by using child restraints properly, as well as actively encouraging the use of these devices.

As per Arrive Alive South Africa: 'Buckling up is the simplest way to save a life. ${ }^{[16]}$

1. Kihurani I, van Niekerk A, van As AB. Child road traffic crash injuries at the Red Cross War Memoria Children's Hospital in Cape Town, South Africa in 1992, 2002 and 2012. Int J Inj Contr Saf Promo 2014;22(4):352-358. https://doi.org/10.1080/17457300.2014.912236

2. Lozano R, Naghavi M, Foreman K, et al. Global and regional mortality from 235 causes of death for 20 age groups in 1990 and 2010: A systematic analysis for the Global Burden of Disease Study 2010. Lancet 2012;380(9859):2095-2128. https://dx.doi.org/10.1016/S0140-6736(12)61728-0

3. Hyder AA, Labinjo M, Muzafar SSF. A new challenge to child and adolescent survival in urba Africa: An increasing burden of road traffic injuries. Traffic Inj Prev 2006;7(4):381-288. https://doi org/10.1080/15389580600942965

4. World Health Organization. Global Status Report on Road Safety 2015. Geneva: WHO, 2015. http:/ who.int/violence_injury_prevention/road_safety_status/2015/en/ (accessed 15 February 2017).

5. Groenewald P, Bradshaw D, Daniels J, et al. Cause of death and premature mortality in Cape Town, 2001 - 2006. Cape Town: South African Medical Research Council, 2008. http://westerncape.gov.za/ Text/2008/11/cause_of_death_and_premature_mortality_in_cape_town_5_november_2008.pdf Text/2008/11/cause_of_dea
(accessed 15 February 2017).

6. Childsafe South Africa. Red Cross War Memorial Children’s Hospital, 1991 - 2016. http://childsafe.org (accessed 6 March 2017).

7. Manby F. Clunk, click - an invention that saved lives for 50 years. Yorkshire Post, 24 August 2009 http://yorkshirepost.co.uk/clunk-click-an-invention-that-s-saved-lives-for-50-years-1-2296965 (accessed 15 February 2017)

8. O'Grady S. The man who saved a million lives: Nils Bohlin - inventor of the seatbelt. The Independent, 18 August 2009. http://independent.co.uk/life-style/motoring/features/the-man-who-saved-a-millionlives-nils-bohlin-inventor-of-the-seatbelt-1773844.html (accessed 15 February 2017).

9. McDermott FT, Hough DE. Reduction in road fatalities and injuries after legislation for compulsory wearing of seat belts: Experience in Victoria and the rest of Australia. Br J Surg 1979;66(7):518-521. https://doi.org/10.1002/bjs.1800660721

10. South Africa. National Road Traffic Act No. 93 of 1996. http://gov.za/sites/gov.za/files/25484_0.pdf (accessed 15 February 2017).

1. Sinclair M. The promotion of road safety by healthcare professionals in South Africa. S Afr Med J 2013;103(9):614-615. https://doi.org/10.7196/SAMJ.7335

2. Kool B, Ryan R, Radice K, et al. A child restraint for every child on every trip. NZ Med I 2014;127(1388):61-65.

13. Recicar J, Barczyk A, Duzinski S, et al. Does restraint status in motor vehicle crash with rollover predict the need for trauma team presence on arrival? An ATOMAC study. J Pediatr Surg 2016;51(2):319-322. https://doi.org/0.1016/j.pedsurg.2015.10.041

14. Kling J, Nicholls T, Ntambeka P, van As AB. Restraint use for child passengers in South Africa. S Afr Med J 2011;101(3):146.

15. South Africa. National Road Traffic Act No. 93 of 1996. Regulation 231(6A). http://www.ndmc.gov.za/ Documents/Regulations/tabid/298/ctl/ (accessed 15 February 2017).

16. Arrive Alive. Child restraints and road safety. https://arrivealive.co.za/ (accessed 15 February 2017).

17. Desapriya E, Fujiwara T, Scime G, et al. Compulsory child restraint seat law and motor vehicle child occupant deaths and injuries in Japan 1994 - 2005. Int J Inj Contr Saf Promot 2008;15(2):93-97. https:// doi.org/10.1080/17457300802080602

18. Roberts MC, Turner DS. Preventing death and injury in childhood: A synthesis of child safety seat efforts. Health Educ Q 1984;11(2):181-193.

19. South Africa. National Road Traffic Act No. 93 of 1996. Regulations: School children and persons no to be conveyed in goods compartment of a motor vehicle for reward. Government Gazette No. 40420 2016. (Published under Government Notice R188.)

20. Van As AB. Paediatric trauma care. Afr J Paediatr Surg 2010;7(3):129-133. https://doi.org/10.4103/01896725.70409 